\title{
Organic fertilization to attenuate water salinity effect on papaya growth
}

\author{
Mônica S. da S. Sousa ${ }^{1}$, Vera L. A. de Lima ${ }^{1}$, Marcos E. B. Brito ${ }^{2}$, \\ Luderlândio de A. Silva ${ }^{1}$, Rômulo C. L. Moreira ${ }^{1}$ \& Carlos J. A. Oliveira ${ }^{3}$
}

${ }^{1}$ Universidade Federal de Campina Grande/Centro de Tecnologia e Recursos Naturais/Unidade Acadêmica de Engenharia Agrícola. Campina Grande, PB. E-mail: moni_shirley@hotmail.com (Corresponding author) - ORCID: 0000-0002-9983-0973; antuneslima@gmail.com - ORCID: 0000-0001-7495-6935; luderlandio.andrade@hotmail.com - ORCID: 0000-0001-9496-5820; romulocarantino@gmail.com - ORCID: 0000-0002-4079-4939

${ }^{2}$ Universidade Federal de Sergipe/Campus do Sertão/Núcleo de Graduação em Agronomia. Nossa Senhora da Glória, SE. E-mail: marcoseric@pq.cnpq.br ORCID: 0000-0001-9087-3662

${ }^{3}$ Universidade Federal da Paraíba/Centro de Ciências Agrárias/Programa de Pós-Graduação em Agronomia. Areia, PB. E-mail: jardeloros@hotmail.com ORCID: 0000-0002-5407-9610

\begin{abstract}
The salinity of water and soil reduces the growth and production of crops, especially the fruit trees, such as papaya. Thus, it is necessary to obtain management alternatives for cultivation under these conditions. Therefore, the objective of this study was to evaluate the growth and phytomass of papaya cultivated under irrigation with saline water and organic fertilization. An experiment was set up using a randomized block design, with the treatments distributed in a $5 \times 2$ factorial scheme, consisting of five levels of salinity of irrigation water $\left(0.6,1.2,1.8,2.4\right.$ and $\left.3.0 \mathrm{dS} \mathrm{m}^{-1}\right)$ and two levels of organic fertilization (10 and $20 \mathrm{~L}$ of bovine manure per plant), with three replications, totaling thirty experimental plots. Growth variables of papaya were evaluated. Papaya plants were negatively affected by irrigation water salinity, with a greater effect on the number of leaves and on dry phytomass of leaves, with no effect of bovine manure levels.
\end{abstract}

Key words: Carica papaya, saline stress, organic matter

\section{Adubação orgânica como atenuante da salinidade da água no crescimento do mamoeiro}

RESUMO: A salinidade da água e do solo reduz o crescimento e a produção de culturas, em especial às fruteiras, como o mamoeiro, sendo necessário obter alternativas de manejo que viabilizem o cultivo sob tais condições. Assim, objetivou-se, com este estudo, avaliar o crescimento e fitomassa do mamoeiro cultivado sob irrigação com águas salinizadas e adubação orgânica. Usou-se o delineamento de blocos casualizados, com os tratamentos distribuídos em esquema fatorial, $5 \times 2$, constituídos de cinco níveis de salinidade da

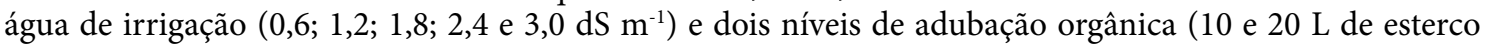
bovino por planta), com três repetições, totalizando trinta parcelas experimentais. Foram avaliadas variáveis de crescimento do mamoeiro. As plantas de mamoeiro foram afetadas negativamente pela salinidade da água de irrigação, com maior efeito no número de folhas e na massa seca das folhas, não havendo efeito dos níveis de esterco bovino.

Palavras-chave: Carica papaya, estresse salino, matéria orgânica 


\section{INTRODUCTION}

Papaya (Carica papaya L.) has great importance for fruticulture due to social and economic aspects, reaching global production of 12.5 million tons in 2013, and its main producers are India, Brazil, Indonesia, Nigeria and Mexico. Brazil, the second largest producer, has $12.6 \%$ of the world production (FAOSTAT, 2015).

In Brazil, papaya is cultivated in all regions, but its production is concentrated in the states of Bahia and Espírito Santo, the two largest producers, which together are responsible for $84 \%$ of the total production, and it is also cultivated in the states of Minas Gerais, Ceará, Paraíba and Rio Grande do Norte, where higher technological levels are used in its production and marketing (CONAB, 2018).

However, in the Northeast region, more than $60 \%$ of the territory is occupied by areas with semi-arid climate (Medeiros et al., 2012), characterized by irregular rainfall and high evapotranspiration rate, naturally causing a water deficit, which limits the growth and development of crops. Thus, irrigated fruticulture, the main form of papaya cultivation in the region, has been the best way to ensure agricultural development.

Nevertheless, in this region, water limitation has contributed to reducing the production of this crop by about 9.6\% (HF BRASIL, 2018), and irrigation has contributed to the accumulation of salts in the soil, causing salinization of irrigated areas (Lima et al., 2014).

The tolerance of crops to salinity and management of practices such as irrigation and fertilization are essential to identify beneficial strategies because, with the expansion of their use to meet the demand for food, the risk of increase in salinized and sodic areas will be imminent (Pinheiro et al., 2013).

Thus, the present study aimed to evaluate the growth and phytomass of papaya cultivated under irrigation with salinized waters and organic fertilization.

\section{Material ANd Methods}

The experiment was conducted from March to October 2014, under field conditions, at the Federal University of Campina Grande - UFCG, Campus of Pombal - PB, Brazil, at geographic coordinates $6^{\circ} 46^{\prime} 12^{\prime \prime} \mathrm{S}$ and $37^{\circ} 48^{\prime} 07^{\prime \prime} \mathrm{W}$, at an altitude of $184 \mathrm{~m}$. According to Köppen's classification, the climate of the region is BSh, hot semi-arid.

Two factors were studied: salinity, corresponding to five levels of irrigation water electrical conductivity $(0.6 ; 1.2 ; 1.8 ; 2.4$ and $\left.3.0 \mathrm{dS} \mathrm{m}^{-1}\right)$; and organic fertilization, relative to two levels of bovine manure (10 and $20 \mathrm{~L}$ per plant). A randomized block experimental design was adopted, in $5 \times 2$ factorial scheme, with three replicates, forming 30 experimental plots, and each plot was composed of two plants of papaya, 'Formosa' group, 'Caliman 01' hybrid, grown in lysimeters/pots with capacity for $150 \mathrm{~L}$, installed at the field.

The control of sprouts and invasive plants was carried out according to the infestation. Pests were controlled preventively, every 15 days, by spraying insecticides. Superficial scarifications were also performed along the experiment in the soil, when it was compacted.

Irrigation with salinized water, according to each salinity level, was manually performed every day using graduated pots, from 30 days after transplanting (DAT), when plants were already adapted to the environment. Irrigation management was carried out by the water balance method, replacing the average daily consumption of the plants and applying an additional fraction. The volume to be applied $(\mathrm{mL})$ was divided by 0.9 to obtain a leaching fraction of 0.10 , which aimed to maintain the balance of salts from irrigation water accumulated in the root zone. The water consumption of each treatment was measured in each irrigation event for replacement in the next irrigations.

The waters used in irrigation were prepared by adding $\mathrm{NaCl}$ to the supply water available at the site, which had EC of $0.3 \mathrm{dS} \mathrm{m}^{-1}$, considering the relationship between ECw and

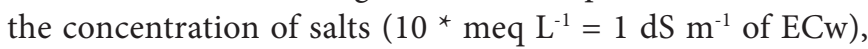
according to Rhoades et al. (1992), valid for ECw from 0.1 to $5.0 \mathrm{dS} \mathrm{m}^{-1}$, which encompass the levels prepared.

After preparation, the waters were stored in $500 \mathrm{~L}$ plastic containers, one for each studied level of ECw, properly protected to avoid evaporation, entry of rainwater and contamination by materials which could compromise quality. Before each irrigation, ECw was measured using a portable conductivity meter, adjusted to temperature of $25^{\circ} \mathrm{C}$.

Nutritional management followed the recommendations proposed by Rigotti (2015), based on soil analysis (EMBRAPA, 2009) after addition of bovine manure, described in Table 1, with weekly fertilizations using urea, potassium chloride $(\mathrm{KCl})$ and monoammonium phosphate (MAP). Micronutrients were applied by foliar sprays at concentration of $1 \%$, at 15 -day intervals.

From 30 days after transplanting (DAT), every month, the following growth variables were measured: plant height $(\mathrm{PH})(\mathrm{cm})$ (from soil to the beginning of the crown), using a millimetric ruler; stem diameter (SD) ( $\mathrm{mm}$ ) (measured at 15 $\mathrm{cm}$ from the soil level), using a digital caliper; and number of leaves (NL), by counting all photosynthetically active leaves. These data were used to obtain the Relative Growth Rate of plant height (RGR-PH) and stem diameter (RGR-SD) in mm $\left(\mathrm{mm} \mathrm{d}^{-1}\right)$ (Taiz et al., 2017).

The total phytomass production of the plant $(\mathrm{g})$ and of each one of its parts were also quantified at the final harvest of the experiment (200 DAT), by destructive analysis. For that, all evaluated plants were separated into shoots (leaves, petioles and stems) and roots.

Table 1. Chemical characteristics of the soil after addition of bovine manure at levels of 10 and $20 \mathrm{~L}$ for cultivation of papaya plants irrigated with saline water at lysimeters

\begin{tabular}{|c|c|c|c|c|c|c|c|c|c|c|c|}
\hline & $\mathrm{pH}_{\mathrm{sp}}$ & $\begin{array}{c}E C_{\text {se }} \\
\left(d^{-1} m^{-1}\right)\end{array}$ & $\underset{\left(\mathrm{ma} \mathrm{dm}^{-3}\right)}{P}$ & $\begin{array}{c}N \\
(\%)\end{array}$ & K & $\mathrm{Na}$ & $\frac{\mathrm{Ca}}{\mathrm{Car}}$ & $\frac{\mathrm{Mg}}{\left.\mathrm{n}^{-3}\right)}$ & SB & $T$ & $\underset{\left(0 \mathbf{k g}^{-1}\right)}{\mathrm{OM}}$ \\
\hline Soil + 10 L & 7.49 & 1.03 & 725 & 0.48 & 0.75 & 0.28 & 3.8 & 3.1 & 7.65 & 10.15 & 8.3 \\
\hline Soil $+20 \mathrm{~L}$ & 8.05 & 1.40 & 739 & 0.48 & 1.46 & 0.45 & 3.7 & 2.8 & 7.96 & 8.41 & 8.3 \\
\hline
\end{tabular}

SB - Sum of bases; $\mathrm{T}$ - Cation exchange capacity at pH 7.0; OM - Organic matter 
Leaves, petioles and stem (stipe) were removed by cutting, whereas roots were removed by sieving the soil contained in the lysimeters, followed by washing, identification and packing.

The plant material was placed in properly identified paper bags, which were dried in an air circulation oven at $65^{\circ} \mathrm{C}$, until constant weight. A digital scale (precision of $0.001 \mathrm{~g}$ ) was used to measure the masses and obtain the phytomass of petiole (PDP) (g), leaves (LDP) (g), stem (StDP) (g), shoots (ShDP) $(\mathrm{g})$, roots $(\mathrm{RDP})(\mathrm{g})$ and root/shoot ratio (RDP/ShDP). The root system was also partitioned into primary root (PRDP) (g) and secondary roots (SRDP) (g).

The obtained data were evaluated by analysis of variance ( $\mathrm{F}$ test up to 0.05 significance level) and polynomial regressions for the quantitative factor (water salinity); for the qualitative factor, organic fertilization, Student's t-test was used, both when there was significance in the $\mathrm{F}$ test, using the program Sisvar 5.3 (Ferreira, 2011).

\section{Results AND Discussion}

The interaction between the studied factors caused no significant effect on plant growth, so the responses of the variables were analyzed separately for each factor (Table 2). The factor manure levels (ML) had no significant effect on any of the variables, evidencing that, although greater amount of the organic fertilizer was supplied to the soil, there was no increment of growth in height, diameter and number of leaves. For the factor irrigation water salinity, it can be noted that there was no significant difference for the variables $\mathrm{PH}, \mathrm{SD}$ and RGR-PH.

The results indicate that these variables were less sensitive to salt stress, and the highest values of $\mathrm{PH}(1.08 \mathrm{~m}), \mathrm{SD}$ $(53.67 \mathrm{~mm})$ and RGR-PH $\left(0.0037 \mathrm{~mm}^{-1} \mathrm{~d}^{-1}\right)$ were observed with

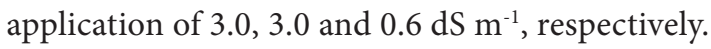

For the number of leaves and RGR-SD, there was significant effect $(\mathrm{p}<0.05)$ with reduction per unit increase in water salinity on order of 11.73 and $11.11 \%$, respectively, considering the means obtained in plants fertilized with 10 and $20 \mathrm{~L}$ of manure (Figures $1 \mathrm{~A}$ and $\mathrm{B}$ ).

Although there was significant effect of water salinity on the relative growth rate of diameter, it was not expressed in the growth of stipe diameter.

Studying the papaya cultivars 'Sunrise Solo' and 'Tainung-1', Sá et al. (2013) found average variation in the number of leaves from 4 and 10 leaves, at the lowest salinity level $\left(1.2 \mathrm{dS} \mathrm{m}^{-1}\right)$, evidencing less sensitivity to salt stress. Based on these data, it can be stated that salt stress negatively affects the formation

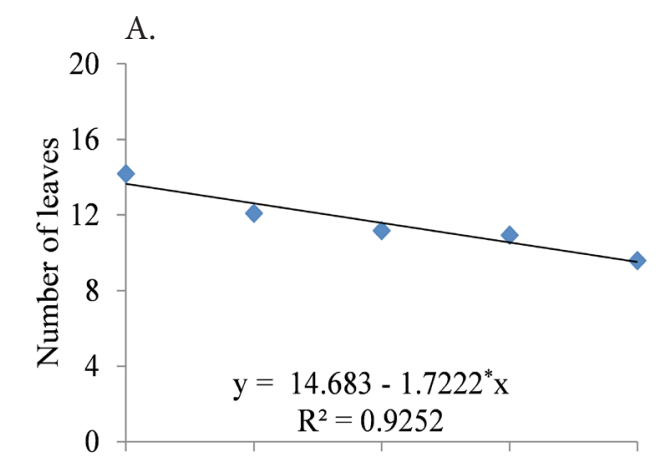

B.

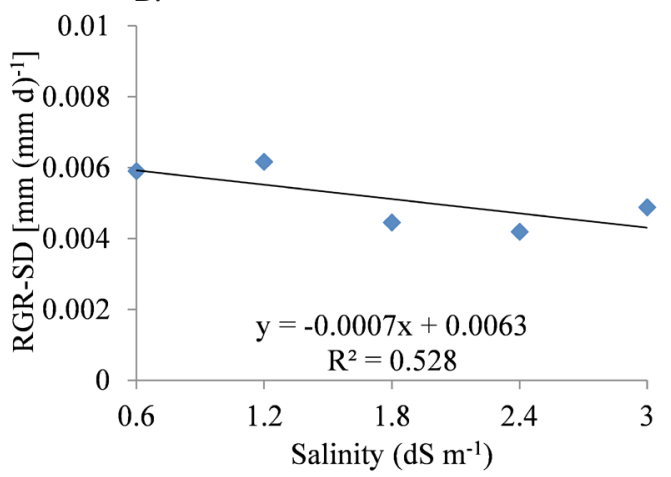

Figure 1. Number of leaves $(A)$ and relative growth rate for stem diameter - RGR-SD (B) of papaya plants (Carica papaya L.) under saline water with mean of manure levels

of leaves, which may be related to both the reduction in the formation of new leaves and also to the visually observed dehiscence of mature leaves, which was not inhibited by the increment in the amount of manure.

For phytomass production, water salinity had significant effect $(\mathrm{p}<0.01)$ on petiole dry phytomass (PDP) and leaf dry phytomass (LDP), and there were no differences among the levels of manure or even effect of the interaction between factors on any of the variables (Table 3). It is worth mentioning that the lack of effect of interaction between the levels of water salinity and manure means that the effect of salinity was similar, regardless of the level of manure used, especially on the formation of petiole phytomass and leaf phytomass.

There was significant effect $(\mathrm{p}<0.01)$ of water salinity on the formation of petiole phytomass (PDP) and leaf phytomass (LDP) (Figure 2). There were reductions in PDP on the order of $21.52 \%$ per unit increase in water salinity under the means obtained in plants fertilized with 10 and $20 \mathrm{~L}$ of bovine manure (Figure 2A). For LDP, the reductions per unit increase in water salinity were on the order of $19.72 \%$ with means obtained in

Table 2. Summary of analysis of variance for plant height (PH) (cm), stem diameter (SD) (mm), number of leaves (NL) and relative growth rates of plant height (RGR-PH) and stem diameter (RGR-SD) in $\mathrm{mm}\left(\mathrm{mm} \mathrm{d}^{-1}\right)$, of papaya cultivated under saline water irrigation $(\mathrm{SAL})$ and organic fertilization $(\mathrm{ML})$

\begin{tabular}{|c|c|c|c|c|c|c|}
\hline \multirow{2}{*}{$\begin{array}{c}\text { Sources } \\
\text { of variation }\end{array}$} & \multirow{2}{*}{ DF } & \multicolumn{5}{|c|}{ Mean square } \\
\hline & & PH & SD & NL & RGR-PH & RGR-SD \\
\hline SAL & 4 & $0.0066^{\text {ns }}$ & $32.164^{\text {ns }}$ & $17.312^{*}$ & $0.000000088^{\mathrm{ns}}$ & $0.000005^{*}$ \\
\hline $\mathrm{ML}$ & 1 & $0.0009^{n s}$ & $95.729^{\text {ns }}$ & $2.408^{\mathrm{ns}}$ & $0.000000073^{\text {ns }}$ & $0.00000026^{\mathrm{ns}}$ \\
\hline SAL x ML & 4 & $0.0156^{\mathrm{ns}}$ & $55.502^{\mathrm{ns}}$ & $2.345^{\mathrm{ns}}$ & $0.000000043^{\mathrm{ns}}$ & $0.00001^{\mathrm{ns}}$ \\
\hline Block & 2 & $0.0001^{\mathrm{ns}}$ & $10.516^{\text {ns }}$ & $2.233^{\mathrm{ns}}$ & $0.000002^{\text {ns }}$ & $0.000002^{\mathrm{ns}}$ \\
\hline Error & 18 & 0.0089 & 39.148 & 4.307 & 0.000000067 & 0.000001 \\
\hline CV (\%) & & 9.01 & 12.57 & 17.92 & 24.86 & 20.25 \\
\hline
\end{tabular}

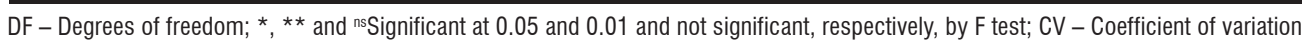


Table 3. Summary of analysis of variance for the phytomass of petiole (PDP) (g), leaves (LDP) (g), stem (StDP) (g), shoots (ShDP) $(\mathrm{g})$, primary root (PRDP) $(\mathrm{g})$, secondary roots (SRDP) (g), all roots (RDP) (g), total (TDP) (g) and root/shoot ratio (RDP/ShDP) of papaya cultivated under saline water irrigation (SAL) and organic fertilization (ML)

\begin{tabular}{|c|c|c|c|c|c|c|c|c|c|c|}
\hline \multirow{2}{*}{$\begin{array}{l}\text { Sources } \\
\text { of variation }\end{array}$} & \multirow{2}{*}{ DF } & \multicolumn{9}{|c|}{ Mean square } \\
\hline & & $\mathrm{PDP}^{1}$ & LDP1 & StDP1 & ShDP1 & PRDP & SRDP1 & RDP & TDP1 & RDP/ShDP \\
\hline SAL & 4 & $1.612^{\star *}$ & $3.670^{\star *}$ & 0.660 ns & $3.450^{\text {ns }}$ & $5.911^{\mathrm{ns}}$ & $0.383^{\text {ns }}$ & $44.670^{\mathrm{ns}}$ & $6.996^{\mathrm{ns}}$ & $0.004^{\text {ns }}$ \\
\hline $\mathrm{ML}$ & 1 & $0.209^{\text {ns }}$ & $0.413^{\mathrm{ns}}$ & 0.226 ns & $0.880^{\mathrm{ns}}$ & $13.068^{\text {ns }}$ & $0.180^{\text {ns }}$ & $47.502^{\mathrm{ns}}$ & $2.070^{\mathrm{ns}}$ & $0.0003^{n s}$ \\
\hline SAL $\times$ ML & 4 & $0.170^{\mathrm{ns}}$ & $0.616^{\text {ns }}$ & 0.520 ns & 0.609 ns & $34.827^{\text {ns }}$ & $0.188^{\text {ns }}$ & 84.512 ns & $1.578^{\mathrm{ns}}$ & $0.003^{n s}$ \\
\hline Block & 2 & $0.715^{\mathrm{ns}}$ & $0.078^{\text {ns }}$ & $1.688^{\mathrm{ns}}$ & $2.021^{\mathrm{ns}}$ & $39.749^{\text {ns }}$ & $0.575^{\text {ns }}$ & 99.967 ns & $4.857^{\mathrm{ns}}$ & $0.0004^{\mathrm{ns}}$ \\
\hline Error & 18 & 0.296 & 0.466 & 1.465 & 1.888 & 16.884 & 0.320 & 50.399 & 3.817 & 0.006 \\
\hline CV (\%) & & 18.38 & 13.42 & 15.64 & 14.08 & 20.32 & 15.64 & 21.10 & 13.06 & 21.69 \\
\hline Overall mean & & 2.96 & 5.08 & 7.73 & 9.75 & 20.22 & 3.62 & 33.64 & 14.96 & 0.35 \\
\hline
\end{tabular}

DF - Degrees of freedom; * ** and ns Significant at 0.05 and 0.01 and not significant, respectively, by $\mathrm{F}$ test; $\mathrm{CV}$ - Coefficient of variation

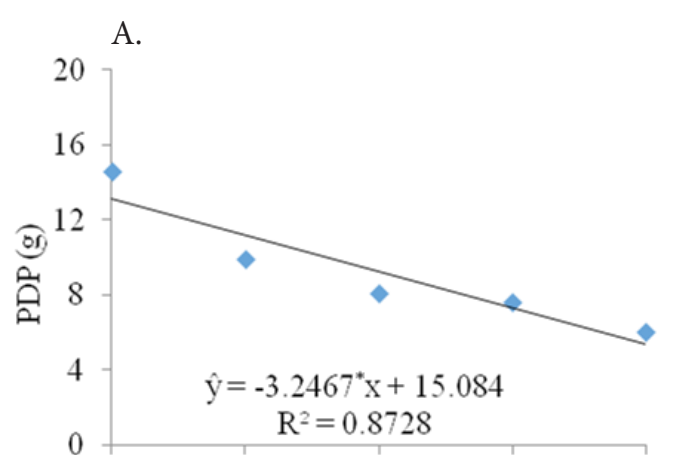

B.

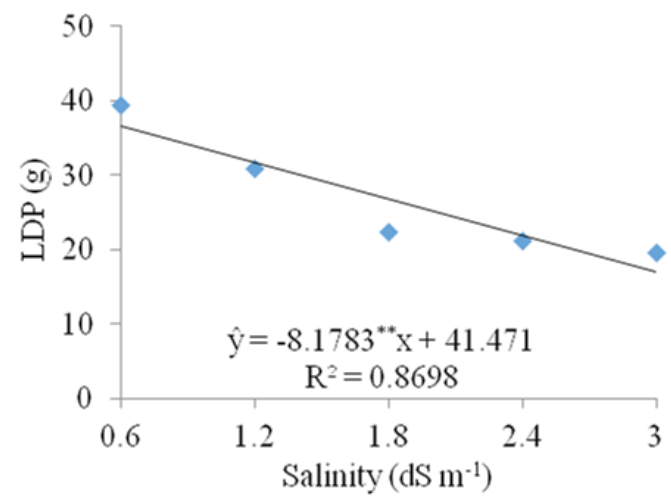

Figure 2. Phytomass of petiole - PDP $(A)$ and phytomass of leaves - LDP (B) of papaya plants (Carica papaya L.) under saline water with means of bovine manure levels

plants fertilized with 10 and $20 \mathrm{~L}$ of bovine manure (Figure 2B), which is consistent with the result observed for petiole phytomass formation, because water salinity caused decrease in plant growth, despite the increase in manure level.

These results confirm that high salt concentrations negatively interacted with the physiology and development of the plants, possibly related to the osmotic effect, which causes restriction in water absorption and turgor, eventually limiting plant growth (Taiz et al., 2017), or there may have been effect of ionic nature, although no visual symptoms of chlorosis or necroes were observed on leaf edges.

Although the increment of manure may improve soil attributes, notably by the action of microorganisms, which can act in the reduction of deleterious effects of salts, allowing for greater allocation of carbohydrates in the shoots (Kaya et al., 2009; Das \& Dang, 2010; Dinesh et al., 2010), in the present study there was no significant positive effect of increasing levels of manure in the soil, since reductions were observed in both PDP and LDP, regardless of the manure level, as water salinity increased.

Pontes (1991), working with manure application in the production of papaya seedlings, observed that manure addition in soil composition led to beneficial effects for plant growth and root phytomass. However, in the present study, such effect was not observed in plants under saline conditions, although the literature reports that organic matter can provide better conditions of structure and water infiltration in the soil (Massad et al., 2014).

Fernandes et al. (2011) report that phytomass formation represents the potential of biomass accumulation and the higher its value, the higher the efficiency of the plant to transform light energy into photoassimilates. Considering this aspect, it can be noted in the present study that the increase in salinity leads to reduction in the efficiency of phytomass formation in papaya plants, especially when the reduction occurs in the leaves.

Reductions in phytomass accumulation due to increase in irrigation water salinity have been observed by Gurgel et al. (2007) in West Indian cherry; by Brito et al. (2008), Rebequi et al. (2009) and Fernandes et al. (2011) in citrus; by Cavalcante et al. (2010) in papaya; by Sousa et al. (2011) and Alves et al. (2013) in cashew, and the effects were mainly osmotic and ionic.

In the literature, papaya is considered as moderately tolerant to salinity (Ayers \& Westcot, 1999; Sá et al., 2013), and it has been observed that salinity limits growth, especially in variables related to the leaves, such as leaf phytomass and leaf area. In plants classified as moderately tolerant, according to classification of Grieve et al. (2012), the salinity threshold is between 2.0 and $4.0 \mathrm{dS} \mathrm{m}^{-1}$. Despite that, in the present study, the reduction of growth, especially in PDP and LDP, occurred from $0.6 \mathrm{dS} \mathrm{m}^{-1}$, which denotes that papaya sensitivity may vary with climate conditions because the plants, naturally, are exposed to more than one condition of stress, that is, the stress is multiple.

\section{Conclusions}

1. Water salinity reduces papaya growth, especially in terms of leaf growth and formation.

2. Increase in the amount of bovine manure did not attenuate the effect of salinity on papaya growth until the evaluated period.

3. Variables related to papaya leaves are more sensitive to salinity, allowing for the indication of the level of sensitivity of these variables to excess salts. 


\section{Literature Cited}

Alves, F. A. L.; Ponte, L. F. A.; Silva, S. L. F.; Maia, J. M.; Silveira, J. A. G. Germinação e estabelecimento de plântulas de cajueiro-anão precoce (Anacardium occidentale L.) em função da salinidade. Revista Brasileira de Ciências Agrárias, v.8, p.197-204, 2013. https://doi.org/10.5039/agraria.v8i2a2062

Ayers, R. S.; Westcot, D. W. Qualidade da água na agricultura. 2.ed. Campina Grande: UFPB, 1999. 153p. Irrigação e Drenagem, 29

Brito, M. E. B.; Fernandes, P. D.; Gheyi, H. R.; Melo, A. S. de; Cardoso, J. A. F.; Soares Filho, W. S. Sensibilidade de variedades e híbridos de citrange à salinidade na formação de porta-enxertos. Revista Brasileira de Ciências Agrárias, v.3, p.343-353, 2008. https://doi. org/10.5039/agraria.v3i4a364

Cavalcante, L. F.; Cordeiro, J. C.; Nascimento, J. A. M. do; Cavalcante, I. H. L.; Dias, T. J. Fontes e níveis da salinidade da água na formação de mudas de mamoeiro cv. Sunrise solo. Semina: Ciências Agrárias, v.31, p.1281-1290, 2010. https://doi.org/10.5433/16790359.2010v31n4Sup1p1281

CONAB - Companhia Nacional de Abastecimento. Boletim hortigranjeiro. Brasília: CONAB, 2018. 72p.

Das, K.; Dang, R. Influence of biofertilizers on stevioside content in Stevia rebaudiana grown in acidic soil condition. Archives of Applied Science Research, v.2, p.44-49, 2010.

Dinesh, R.; Srinivasan, V.; Hamza, S.; Manjusha, A. Short-term incorporation of organic manures and biofertilizers influences biochemical and microbial characteristics of soils under an annual crop Turmeric (Curcuma longa L.). Bioresource Technology, v.101, p.4697-4702, 2010. https://doi.org/10.1016/j.biortech.2010.01.108

EMBRAPA - Empresa Brasileira de Pesquisa Agropecuária. Manual de análises químicas de solos, plantas e fertilizantes. 2.ed. Brasília: Embrapa Informação Tecnológica, 2009. 628p.

FAOSTAT - Food and Agriculture Organization of the United Nations. 2015. Available on: <http://faostat3.fao.org/home/e $>$. Access on: Set. 2017.

Fernandes, P. D.; Brito, M. E. B.; Gheyi, H. R.; Soares Filho, W. S.; Melo, A. S. de; Carneiro, P. T. Crescimento de híbridos e variedades porta-enxerto de citros sob salinidade. Acta Scientiarum. Agronomy, v.33, p.259-267, 2011.

Ferreira, D. F. Sisvar: A computer statistical analysis system. Ciência e Agrotecnologia, v.35, p.1039-1042, 2011. https://doi.org/10.1590/ S1413-70542011000600001

Grieve, C. M.; Grattan, S. R.; Maas, E. V. Plant salt tolerance. In: Wallender, W. W.; Tanji, K. K. (eds.). Agricultural salinity assessment and management. 2.ed. Reston: ASCE, 2012. p.405459.

Gurgel, M. T.; Fernandes, P. D.; Gheyi, H. R.; Santos, F. J. S.; Bezerra, I. L. Uso de águas salinas na produção de mudas enxertadas de aceroleira. Revista Caatinga, v.20, p.16-23, 2007.
HF BRASIL - Hortifrúti Brasil. Anuário hortifrúti Brasil 2017-2018. 16.ed. São Paulo: HF Brasil, 2018. 54p.

Kaya, C.; Ashraf, M.; Sonmez, O.; Aydemir, S.; Tuna, A. L.; Cullu, M. A. The influence of arbuscular mycorrhizal colonisation on key growth parameters and fruit yield of pepper plants grown at high salinity. Scientia Horticultura, v.121, p.1-6, 2009. https://doi. org/10.1016/j.scienta.2009.01.001

Lima, G. S.; Nobre, R. G.; Gheyi, H. R.; Soares, L. A. A.; Silva, A. O. Crescimento e componentes de produção da mamoneira sob estresse salino e adubação nitrogenada. Revista Engenharia Agrícola e Ambiental, v.34, p.854-866, 2014. https://doi. org/10.1590/S0100-69162014000500005

Massad, M. D.; Oliveira, F. L. de; Fávero, C.; Dutra, T. R.; Quaresma, M. A. L. Desempenho de milho verde em sucessão a adubação verde com crotalária, submetido a doses crescentes de esterco bovino, na caatinga mineira. Magistra, v.26, p.322-332, 2014.

Medeiros, P. R. F.; Duarte, S. N.; Uyeda, C. A.; Silva, Ê. F. F.; Medeiros, J. F. de V. Tolerância da cultura do tomate à salinidade do solo em ambiente protegido. Revista Brasileira Engenharia Agrícola e Ambiental, v.16, p.51-55, 2012. https://doi.org/10.1590/S141543662012000100007

Pinheiro, G. G.; Zanotti, R. F.; Costa Paiva, C. E. C.; Lopes, J. C.; Gai, Z. T. Efeito do estresse salino em sementes e plântulas de feijão guandu. Enciclopédia Biosfera, v.9, p.902-912, 2013.

Pontes, H. M. Substratos para a produção de mudas de mamoeiro (Carica papaya L.) na Amazônia Ocidental. Revista da Universidade do Amazonas, v.1, p.57-64, 1991.

Rebequi, A. M.; Cavalcante, L. F.; Nunes, J. C.; Diniz, A. A.; Brehm, M. A. da S.; Beckmann-Cavalcante, M. Z. Produção de mudas de limão cravo em substrato com biofertilizante bovino irrigado com águas salinas. Revista de Ciências Agrárias, v.32, p.219-228, 2009.

Rhoades, J. D.; Kandiah, A.; Mashali, Q. M. The use of saline waters for crop production. Rome: FAO, 1992. 133p. Irrigation and Drainage Paper, 48

Rigotti, M. Cultura do mamoeiro. Disponível em: <http://www. portaldahorticultura.xpg.com.br>. Acesso em: Abr. 2015.

Sá, F. V. da S.; Brito, M. E. B.; Melo, A. S.; Antônio Neto, P.; Fernandes, P. D.; Ferreira, I. B. Produção de mudas de mamoeiro irrigadas com água salina. Revista Brasileira de Engenharia Agrícola e Ambiental, v.17, p1047-1054, 2013. https://doi.org/10.1590/ S1415-43662013001000004

Sousa, A. B. O.; Bezerra, M. A.; Farias, F. C. Germinação e desenvolvimento inicial de clones de cajueiro comum sob irrigação com água salina. Revista Brasileira de Engenharia Agrícola e Ambiental, v.15, p.390-394, 2011. https://doi. org/10.1590/S1415-43662011000400010

Taiz, L.; Zeiger, E.; Møller, I. M.; Murphy, A. Fisiologia e desenvolvimento vegetal. 6.ed. Porto Alegre: Artmed, 2017. 880p. 